\title{
COMMUNITY DEVELOPMENT CORPORATIONS: THE PROBLEM OF MIXED OBJECTIVES
}

\author{
Fredertck D. Sturdivant*
}

In commenting on the urban riots of the I96o's, W. H. Ferry has noted that the most important force to emerge "was the explosive renascence of the idea of black manhood, of black dignity and worth, of the black's desire to run his own affairs." Ferry added that he regarded "this welling-up within the black psyche as a permanent force in our national life and a matter for great rejoicing." Indeed, this rebirth of racial pride is the foundation for much of the discussion and activity centering around the concept of community development corporations (CDC).

In any discussion of community development corporations it is important to distinguish between those already established corporate entities (of which there are some one hundred in the United States) and the provisions contained in the Community Self-Determination Bill ${ }^{2}$ which was introduced during the Ninetieth Congress. This paper will focus primarily on the organizational effectiveness of the existing community or local development corporations rather than on the provisions of proposed legislation designed to accelerate the expansion of such corporations. It should also be noted that while a number of these established CDC's are operated by low-income American Indian and Mexican-American communities in rural as well as urban areas, this paper will primarily treat the role of the CDC's in black urban ghettos.

In general, these corporations are "community-based organizations that conduct revenue-generating business with the primary purpose of economic and social development of their community."3 In most cases these CDC's either involve or ultimately call for widespread ownership of shares in the corporation by members of the local community. Furthermore, most of the earnings of the business usually are committed to community well-being rather than to the economic enhancement of individual shareholders. While the specific organizational forms among the various community development corporations vary widely, it should be possible to treat the question of whether such a type of corporate ownership provides an effective base upon which to construct viable economic-social institutions. In approaching the problem, it will be necessary to analyze the types of challenges facing those who would create and direct such corporations in their communities, and to evaluate the capability of these organizations to surmount those challenges.

* Associate Professor, Harvard University School of Business Administration.

I am indebted to my research assistant, Steven L. Diamond, and to Miss Elizabeth Burnham, Associate in Research, for their assistance and comments on this paper.

${ }^{1}$ Ferry, The Case for a New Federalism, Saturday Review, June 15, 1968, at 14.

S. 3876 , goth Cong., 2d Sess. (Ig68).

Note, Community Development Corporations: Operations and Financing, 83 Harv. L. REv. I559, I560 (I970). 
Fields of study ranging from architecture to biology to organization theory suggest that organisms must be adaptive to their environment if they are to be effective-indeed, if they are to survive. A closely related matter is the issue of resources. An organizational form must be evaluated not only in terms of the availability of resources such as capital and expertise, but also with respect to the capacity of the organization to marshall these resources through effective management. Finally, the objectives of the enterprise must be evaluated in light of the environment and the resources of the organization.

\section{The Business Environment of the Neighborhood}

The rediscovery of poverty by the dominant society in the United States during the I960's produced a seemingly unending series of portraits of the physical and emotional decay that characterizes the urban slum. Most of the books, articles, television documentaries, and speeches treating poverty in the United States focused on the most visible and seemingly fundamental aspects of the problem: education, medical care, housing, and unemployment. The issue of business development within the ghetto, however, was largely ignored. Even the discussions of unemploymnet generally concentrated on training and employment opportunities in businesses outside the ghetto. Gradually, however, it came to be recognized by people both inside and outside these depressed areas that economic development was central to dealing effectively with the nation's urban crisis.

An important segment of any economy is the retail sector. The state of its health is often a vital sign of the overall well-being of the community. This is indeed the case in black ghettos. As psychologist Kenneth Clark has noted, "The dark ghetto is not a viable community. It cannot support its people; most have to leave it for their daily jobs. Its businesses are geared toward the satisfaction of personal needs and are marginal to the economy of the city as a whole." He further explains that "It has few large businesses. Most of its businesses are small, with what that implies in terms of degree of stability...." ${ }^{\text {Th }}$ The structure of the retailing communities in black ghettos can be best described as atomistic. That is, the predominant form of retail establishment is the small, owner-operated "mom-and-pop" store.

Mass merchandising firms are seriously underepresented in such areas. Clark notes, for example, that in 1965 there was only one large department store in Harlem. In most cases where units of large chain organizations are found in ghetto locations, such stores were established in a period when the area was neither economically depressed nor black. There are generally a few "middle-sized" retail firms often dealing in appliances or groceries, and there are the ubiquitous door-to-door peddlers. It is often in these two categories, as opposed to the the mom-and-pop operations or large retailers, that parasitic practices are found. The inflated prices, bait-and-switch sales techniques, misrepresentation of goods, and illegal rates of interest that have

\footnotetext{
'K. Clark, Dark Ghetto 27-28 (1965).
} 
been documented by David Caplovitz and others too often characterize the buyerseller relationship in the ghetto. ${ }^{5}$

Inefficiency, however, is an even more significant feature of the ghetto marketplace than exploitation. Inefficiency not only characterizes the generally undercapitalized and poorly managed mom-and-pop stores, but also the consumers who patronize the retail establishments. It is, for example, inefficient to shop frequently and purchase in small lots. This kind of buying behavior maximizes wear-and-tear both on the shopper and on the facilities of the retailer. It eliminates the opportunity for savings through quantity purchases and increases the cost per transaction. Heavy reliance on credit is also inefficient in that the interest charges consume many dollars that could otherwise be used to purchase needed goods and services.

These inefficiencies on the part of the consumer are largely explained by lowincome. How can large quantities be purchased when the income is meager? How can large quantities of food, for example, be purchased when not only the income is limited but also the consumer's storage facilities? These limitations coupled with relative immobility of the customer group also discourage comparative shopping and bargain hunting beyond the bounds of the ghetto.

The shopping behavior of the area residents represents only one set of problems faced by the ghetto retailer. While he is often pictured as a nefarious exploiter who every evening tosses a money-stuffed bag in the trunk of his Cadillac and drives off to the suburbs, the description is grossly misleading. A study by the Federal Trade Commission in the Washington, D.C. area of ten low-income market retailers and ten general market retailers of furniture and appliances revealed the following:

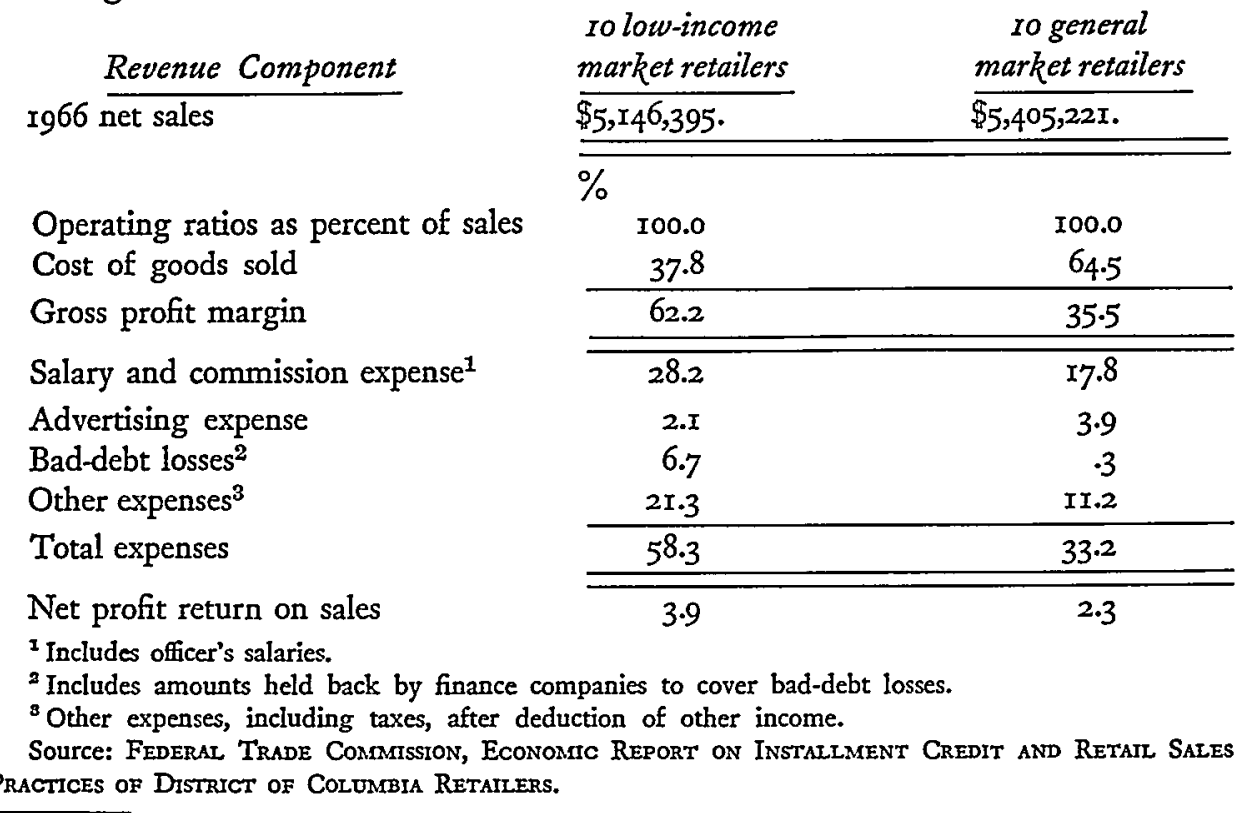

${ }^{5}$ D. Caplovitz, The Poor Pay More (1963); The Ghetto Marketplace (F. Sturdivant ed. I969). 
It can be seen that the substantially higher gross margins are largely consumed by personnel expenses, bad-debt losses, and other expenses which are higher in ghetto locations. Problems of insurance rates, vandalism, and theft are reported to be major problems for ghetto retailers. Indeed, the same FTC report found that while net profit as a percent of sales was higher in the ghetto stores studied, the return on investment was substantially lower than in comparable general market stores. (These data include other stores in the FTC sample in addition to the 20 low-income and general market retailers noted above.)

\begin{tabular}{|c|c|c|}
\hline Type of retailers & $\begin{array}{l}\text { Net profit } \\
\text { after taxes as } \\
\text { a percent of } \\
\text { sales }\end{array}$ & $\begin{array}{l}\text { Percent rate of } \\
\text { return after taxes on } \\
\text { on stockholders' equity }\end{array}$ \\
\hline $\begin{array}{l}\text { Low-income market retailers } \\
\text { General market retailers: }\end{array}$ & $4 \cdot 7$ & IO.I \\
\hline $\begin{array}{l}\text { Appliance, radio, and television } \\
\text { stores }\end{array}$ & 2.1 & 20.3 \\
\hline $\begin{array}{l}\text { Furniture and home-furnishing } \\
\text { stores }\end{array}$ & 3.9 & 17.6 \\
\hline Department stores & 4.6 & 13.0 \\
\hline
\end{tabular}

Source: Federat Trade Commission, Econonmc Report on Installment Credit and Retail Sales Practices of District of Coltumbia Retailers.

In addition to having limited income opportunities, ghetto merchants are also faced with community hostility. The fact that most retail establishments are whiteowned and controlled by outsiders is the cause of much of the bitterness. As Clark notes, "Property-apartment houses, stores, businesses, bars, concessions, and theaters -are for the most part owned by persons who live outside the community and take their profits home." While black-owned businesses have not escaped looting and destruction during riots, much of the dialogue and action associated with efforts by black people to gain local control of economic institutions is based on the bitterness toward white-owned businesses.

Although the role of the manufacturing sector of the ghetto economy is less well documented than that of retailing, it is clear that the industry suffers many of the same environmental problems. James $L$. Sundquist has summarized the basic elements of the problem as follows:

The realities of land and production economics suggest that the possibilities of ghetto industry, without substantial subsidies-and possibly even with them-are severely limited. Vacant land is often scarce and costly. Existing commerical buildings are cramped and outmoded. The ghetto labor force lacks skill and experience. Insurance rates are high. So are the city tax rates. Transportation for materials and products is expensive. For all these reasons, ghetto industries are usually at a marked competitive disadvantage. ${ }^{7}$

\footnotetext{
${ }^{6} \mathrm{~K}$. Clark, supra note 4 , at 28.

${ }^{7}$ Sundquist, $70 b s$, Training, and Welfare for the Underclass, in AGENDA FOR THE NATTON 57 (1968).
} 
These barriers to success in part explain why less than one percent of the manufacturing enterprises in the United States are black-owned. ${ }^{8}$

Thus, if one combines the economic forces which have a direct impact on ghetto retailing and manufacturing establishments with the dismal conditions that often prevail in the schools, the problem of narcotics and crime, and the pervasiveness of the dehumanizing and inadequate welfare programs, it can be seen that the total environment for business is not attractive. These factors pose a major challenge to the operation of any successful business whether it be a community corporation or some other form of enterprise.

Does an organization owned by local citizens and committed to the social as well as economic well-being of the community have any unique advantages in dealing with the environmental forces which have been noted? Clearly if the local development corporation is successful in getting wide-spread community involvement and creates an esprit de corps among the shareholders, employees, and managers, it may be able to deal effectively with the problem of hostility toward business. It is important to note that if success is achieved in this area, the corporation's chances of survival will have been increased.

Assuming that the CDC spirit does spread through the community, the organization still faces a number of very difficult problems. The CDC certainly does not offer any unique advantages in dealing with the atomistic structure of the ghetto retailing community. Indeed, a number of these corporations have achieved little more than transferring the ownership of inefficient mom-and-pop stores from white to black hands. The most notable attack by a community corporation on the problem of the scale of ghetto enterprises has been made by Zion Investment Associates, Inc., the Reverend Leon Sullivan's well-known Philadelphia-based company. Unfortunately, the fact the Sullivan's enterprises stand out is a reflection of their atypical scale of operation.

Perhaps the most crucial of the challenges are those related to efficiency. The issues of costs, profitability, and customer satisfaction are, of course, interrelated. In order to attain maximum levels of profitability a business must control costs. For the new enterprise, it is especially difficult to arrive at the proper level of expenditures for payroll, supplies, rent, and the like. For example, the general manager of Shindana, the Operation Bootstrap manufacturer of black dolls, has reported: "That first year was a messed-up year. We didn't know anything about business. We had more so-called white-collar workers than factory workers. Then last year, we had about 75 workers. This year we have $65 . " 10$ It should be noted that these reductions were made during a period when output of the manufacturer increased sharply.

\footnotetext{
'The Thirty-fifth Americhn Assembly, Black Economic Development 5 (1969).

- For description of Zion Investment Associates, Inc., see J. Hund, Black ENTrEpreneurship 59-6r (1970); Community Development Corporations: Operations and Financing, supra note 3, at $1562-67$.

${ }^{10}$ Shindana Discovers the "Together" Dolls, BlAck EnTERPrise, Dec. 1970, at 24, 25.
} 
Many of the costs of doing business in the ghetto, as noted above, are external to the firm. These costs are especially burdensome for the ghetto enterprise that must retain the patronage of its local customers and be competitive in the outside market. According to James M. Hund, "In order to compete, both in the ghetto setting and in the wider market, black enterprises beyond the scope of the 'mom and pop' grocery must be able to offer the same quality of services as white counterparts competitively located."11 One of the unfortunate myths contained in much of the rhetoric surrounding the CDC concept is that "buy black" campaigns will assure black enterprises a guaranteed market. However, as ghetto residents become more affluent and mobile and as racial barriers diminish, the retailers in those areas face increasing competitive pressures. Theodore Cross has suggested that "The Negro entrepreneur is being buffeted by pressures from . . . the growing affluence of his once-captive customers. The mortician, the beautician, the barber is finding much of his clientele deserting him for stronger and 'more prestigious' white competitors."12 Even the few black-owned firms which have operated in the national market, such as the Supreme Life Insurance Company, have faced intensified efforts of "white" companies to penetrate their traditional markets.

In sum, if the community development corporation's businesses are to be viable, they must have effective control over their internal costs and work to offset those external cost differentials which place them at a competitive disadvantage with firms operating in the general economy. While ethnocentrism is increasingly a fact of life in black communities, it would be dangerous to assume that even local customers will remain loyal if more attractive competitive alternatives are available to them.

\section{II}

\section{Neighborhood Resources}

A major determinant of whether or not any enterprise can meet such a challenge will be the resources it has at its command. The essential ingredients in creating a successful business can perhaps be summarized as follows: entrepreneurship, managerial skill, and financial strength. ${ }^{13}$

"Entrepreneur" is a much abused word. Often used to describe the MBA who becomes a junior executive in a giant corporation, it also frequently is applied to the owner of the corner gasoline station. Instead, it should be thought of in the Schumperterian sense of the word-innovative, driving men who are agents for change because they conceive of new relationships between products, services, and markets and possess the courage to assume the high risks associated with launching enterprises committed to exploiting those opportunities. They are the type described by Lenin's teacher, G. V. Plekhanov:

\footnotetext{
${ }^{11} \mathrm{~J}$. Hund, supro note 9, at 25-26.

12 T. Cross, Black Capitalism 62 (1969).

${ }^{13}$ The most obvious omission from this list is labor. However, there are no labor problems that are essentially unique to CDC's, and thus the topic is not discussed here.
} 
The more or less slow changes in "economic conditions" periodically confront society with the necessity of more or less rapidly changing its institutions. This change never takes place "by itself"; it always needs the intervention of men, who are thus confronted with great social problems. And it is those men who do more than others to facilitate the solution of these problems who are called great men. ${ }^{14}$

Does the black community have such men among its numbers? One need only observe the charismatic leadership of articulate and dynamic men within the community to be convinced that the potential seems to exist. Because of racism in the dominant society and the absence of a business heritage among blacks, these talents have often gone untapped or else they have been unleased in other directions; but the potential exists. This view was expressed excellently by Elmer Young, as associate of Leon Sullivan, during a conference on community-based economic development at the Cambridge Institute.

All of us are starting out as infants in a man's world. If you told me back in 1962 that Elmer Young was going to develop a shopping center I'd have said, "You're crazy." Same thing with Lou Smith who I knew back in Philadelphia. If I'd said, "Lou, you'll be president of a company making black dolls," he'd have told $m e$ I was crazy. But we had the guts to try it. And I think that's what any black group has to have. You have to stand up and there and say, "White folks can do this, and we can too." This doesn't mean you're not going to stumble. We still have to stumble. ${ }^{15}$

Will community-based forms of organization provide the appropriate mechanism for attracting the talents of local entrepreneurs? Certainly in a limited number of cases they have. Leon Sullivan is probably one of the outstanding entrepreneurs produced by this country in recent years. In too many cases, however, the CDC's have done little more than encourage the development of a class of marginal shopkeepers. Perhaps the essential point to be made is that a black entrepreneur may well view the $\mathrm{CDC}$ as one of a number of attractive avenues to be considered along with traditional corporate organizations, partnerships, sole proprietorships, and the like. He must have the freedom to select from among these alternatives the organizational form that is best suited to the opportunities which he has identified. One of the more unfortunate features of the Community Self-Determination Bill was that because of certain tax provisions and lending arrangements, it would have discriminated against existing and would-be entrepreneurs who elected not to participate in the CDC. ${ }^{16}$ Any legislation designed to stimulate economic development in the inner-city should not unnecessarily restrict the freedom of action for these agents of change by granting discriminatory advantages to one particular organizational form.

The qualities of innovativeness, drive, and a high propensity for risk taking

\footnotetext{
${ }^{16} \mathrm{~J}$. Hughes, The Vital Few I $_{4}$ (I966).

${ }^{16}$ The Cambridge Institute, Community Based Economic Development, June, r970, at i8.

${ }^{10}$ Sturdivant, The Limits of Black Capitalism, HaRv. Bus. REv., Jan.-Feb., 1969, at 122, 124-25.
} 
that distinguish the entrepreneur do not necessarily make him a good manager of a firm's day-to-day operations. An additional resource that is vital to community economic development, therefore, is managerial talent. Such skills are acquired through formal education or practical experience or some combination thereof. Because of barriers to full participation by blacks in business in the past, the pool of experienced managers in the community is quite shallow.

One of the challenges facing the community corporation, therefore, is to compete effectively for experienced black managers. The black community orientation of the business will in itself represent a strong appeal to many who feel that they have not received equal opportunities in white businesses. Two examples can be cited from Shindana, the black doll company. Phil Gilyard who is $3^{8}$ and general manager of the company explains that he "was an administrative supervisor at Hughes Tool Company and I couldn't go any farther. I took this job not for the money, but to develop my management potential." Thirty-five year old foreman Ralph Reggin left Eldon Industries, another toy company, where he was a supervisor and came to Shindana at a lower salary. "I felt that I would only go so far because of its being a white company. Here, I can go any place and I'm doing something for the black."17

In spite of the strong appeal of "doing something for the black," it is unlikely that experienced managers can be attracted and retained unless they feel the enterprise has sufficient potential to offer them a challenge and an opportunity to develop their "management potential." Thus CDC's must undertake ventures which have excellent growth potential. At the same time they must recognize that their internal organizational structure must allow for maximum managerial freedom in conducting the affairs of the business. The community ownership and social development objectives of many of the local development organizations pose a number of difficulties which will be discussed more fully below. In terms of its implications for management, perhaps a brief analogy with cooperatives will be sufficient.

In its purest form the managerial atmosphere of a community development corporation closely resembles that of a cooperative. As the Cambridge Institute bulletin puts it, "A CDC is simply a corporation based in one geographic area and controlled democratically by the residents." 18 This is not to suggest that all CDC shareholders vote on every management decision. In addition to the traditional board of directors, however, there generally exists a business management board or some such body composed of local residents who are responsible for the management of the enterprise. Democratic management, whether it be in a cooperative or a CDC, according to James Hund "can be stultifying to the conduct of the business."10 It is not difficult to imagine the frustrations that would be encountered by an experienced manager in such situations. Indeed, it is probably safe to say that the greater the

\footnotetext{
${ }^{17}$ Shindana Discovers the "Together" Dolls, supra note 10, at 26-27.

${ }^{18}$ The CAMbridge INSTITUTE, supra note 15 , at $\mathrm{r}$.

${ }^{10} \mathrm{~J}$. HAND, supra note 9 , at $6_{5}$.
} 
degree of democracy in the enterprise, the less effective its management will be. This weakness is clearly a major flaw in the concept of community-based development corporations.

The third critical resource which needs to be considered is financing. Community development corporations have drawn on a wide range of sources for funds. The Hough Area Development Corporation in Cleveland received its initial capital in the form of a $\$ 1.6$ million Special Impact grant from the Office of Economic Opportunity. Subsequently, to found a rubber company, Hough raised an additional $\$ 350,000$ through a Small Business Administration loan guarantee. The Operation Bootstrap company, Shindana, received its initial \$200,000 gratis from Mattel, Inc. Another corporation, El Mercado de Los Angeles, raised \$1,040,000 for a shopping facility housing forty small businesses in the Mexican-American barrio, the money being obtained through loan under the provision of the Small Business Investment Act of 1958 . In addition, some $\$ 260,000$ was raised in the community through the sale of stock. Zion Investment Associates, Inc., in Philadelphia raised its initial capital through the monthly investments of some 200 members of Sullivan's Zion Baptist Church. The ro-36 plan (\$10 per month for 36 months) began in 1962 . The corporation now has some r,000 shareholders and an additional 6,000 persons are making installment payments for shares. Additional funds have been raised through loans from banks.

The Harvard Law Review has reported that managements of ten of thirty community development corporations interviewed had "acquired sufficient funding for substantial business activity and [had] begun operating such businesses." ${ }^{20}$ In each case, however, even these organizations "were struggling to secure additional venture capital to allow continuation and growth of their businesses."21 Another third of the organizations interviewed were operating on a very small scale, generally fewer than ten employees, and had received little outside financial or technical assistance. The remaining third had not yet launched their business operations, but several had received funding commitments for operations which were in an advanced stage of planning.

The key to raising funds, either equity, debt, or gifts is, the viability of the enterprise. Investors, loan officers, and benefactors must have confidence in the leadership of the company. This confidence is enhanced by the existence of a wellplanned and well-managed venture that holds good promise of achieving its objectives. For the investor and the lending institution the ultimate objective must be the generation of sufficient profits to protect the investment or to repay the debt. Even the funds received by outright grant must be received on the assumption that the funds will assist in the creation of a viable business that will produce long-range benefits for the participants and the community. Thus the definition of the community corporation's goals is closely related to its capability to raise capital.

\footnotetext{
${ }^{20}$ Community Development Corporations: Operations and Financing, supra note 3 , at 1576 . ${ }^{21} I d$.
} 


\section{III}

\section{The ObJectives of the CDC}

The major problem facing community-based development corporations is the formulation, adoption, and achievement of goals and objectives. The people who come together to create or to participate in virtually any kind of organization generally share in a complex set of goals. Even the traditional business corporation is clearly more than an economic institution. However, its fundamental objectiveto make a profit-is well-defined and provides the basis which makes the achievement of all of its other goals possible.

The goals of most CDC's are highly complex and in many cases they make the attainment of this fundamental objective of long-range economic viability difficult if not impossible. While community-based development corporations are not legally bound to the goals called for in the Community Self-Determination Bill, most are committed to similar objectives. Therefore, it is useful to consider what the Harvard Law Review described as the three primary goals of the CDC:

First, as a political institution, it provides a mechanism through which the poor can achieve meaningful participation in the control of significant aspects of their community life. Second, the CDC as a service organization provides needed services to the community while avoiding the handout syndrome surrounding public welfare. Third, as an economic institution, the CDC promotes the economic development of the community through investment in community businesses.22

The article notes that the draftsmen of the bill viewed economic development as the most important function. However, Gar Alperovitz, a coauthor of the original bill has emphasized that all three goals are essential elements of the legislation:

The critical word in the legislation is community development. I want to distinguish that from economic development, because the whole assumption of community development is that jobs or the ownership of stock-either one aloneis insufficient to deal with some of the critical problems of the ghetto. The view here, which relates to community participation and the poverty program, is that some way must be found to bring together some form of cohesive unit in the ghetto, and that is the critical first assumption you must begin with. Thereafter, the questions of economic development, transfer of resources, jobs and capital come up. 23

Thus Alperovitz views the creation of a sense of community of the forming of a cohesive unit in the ghetto as a necessary precondition to economic development. Alperovitz also explains the linkage between social services and the community's business operations.

\footnotetext{
${ }^{22}$ Note, Community Development Corporations: A New Approach to the Poverty Program, 82 Hanv. L. REv. 644,645 (1969).

${ }^{28}$ A Dialogue on Community Self-Destruction: Problems and Potential, New Generation, Fall, 1968, at 22.
} 
What we are trying to do here is to get away from bureaucratic administration of various social service programs. We are attempting to transfer to the people in the community control over decisions that affect their lives. In one sense this approach has grown out of the experience of projects like Crawfordville, a Georgia textile operation which is essentially a non-profit, one-man, one-vote community corporation, like a co-op, only it doesn't give dividends at this stage.

What this new legislation proposes is to link the social services controlled by a community with an economic profit-making enterprise. ${ }^{24}$

The soundness of this organizational form as a vehicle for a dramatic transformation of the nation's ghettos rests with the compatibility of its political and social goals with its economic goals.

\section{A. Compatibility of Political and Economic Goals}

The political goals center around community control of economic resources and social services and widespread community participation in the decision making process. Implicit in much of the discussion of political goals, however, is the development of a power base within the community which can be used to deal with outside agencies such as the city or the federal government.

The demand for local control over economic institutions is an interesting anachronism in an era of conglomerates, chain stores, and franchising. While there has been some resistance to these forces throughout the society, the resistance generally has been based on the increasing dissatisfaction with the depersonalization and sameness of the strings of hamburger stands, fried chicken establishments, muffler and automatic transmission repair shops, and discount houses that have spread from coast to coast to deface the landscape. In the ghetto, however, hostility has grown out of years of bitterness associated with the inefficiency, corruption, and insensitivity of the businesses and governmental agencies with whom the residents of the ghetto have normally interacted. Therefore, the desire for local control is understandable. But is it feasible?

If the community corporation had the resources needed to gain control of extant businesses, create new growth firms within the ghetto, and manage these enterprises without outside assistance, then such an objective as local control might well be within its reach. However, when the community corporation turns to outside sources for the capital that is needed, it necessarily incurs restrictions on its freedom of action. Private sources of funds are reluctant at best either to invest equity dollars in or make loans to ghetto enterprises because the risks of failure are greater than in nonghetto businesses. Therefore, it is not at all uncommon for restrictions to be placed on the use of the funds, the qualifications for members of the management group and the types of businesses to be established or acquired. And certainly restrictions of this kind are imposed when federal funds are obtained be they from the Small Business Administration, the Office of Economic Opportunity, or other agencies.

\footnotetext{
24Id.
} 
In the same manner, local groups may find encumbrances resulting from the use of outside experts. As Bernard Gifford of FIGHT in Rochester has indicated, the outside consultant may speak a very different language and his role may ultimately be determined by the funding source:

The white individual who comes in to offer his expertise has to think differently. Basically you have to decide which side of the fence you're talking about: profits or people. If your motivation is detemined by material gain instead of by human beings, then you're going to find yourself hung up in the same kind of situation that created these problems in the first place. People who don't share this kind of philosophy-that people are more important than profit-work against you .... . Do-gooders who want to come down and give some input may have a lot of expertise in some areas, but they have to be willing to listen to people here with good ideas about what their community needs, what's best for their community, and then try to work out the solutions to do that, which is contrary to the present system. Under this system, your funding source dictates how things are to get done. ${ }^{25}$

The dilemma of outside resources suggests that the more self-sufficient the local corporation the greater the degree of local control possible. If substantial seed money can be raised within the community, as in the case of Zion in Philadelphia, then the corporation is in a stronger position to minimize restrictions tied to outside funds. As Elmer Young explains, "We ... had to establish credibility. But I'll tell you one thing, a few hundred thousand dollars in a banker's face did an awful lot to help us."28 Credibility is more readily established, as well, when the management of the community corporation has established programs which are consistent with traditional management practices. Indeed, if the economic structure of the ghetto is to undergo dramatic transformation, it may be necessary that even the strongest community corporations compromise their desire for complete control by inviting outside firms to participate in community-inspired plans for business development. Such, for example, was the case in the Progress Plaza shopping center in Philadelphia. Six of the sixteen units in the center are "white" businesses which not only helped secure financing but also reflected the results of a consumer study conducted in the area to determine the desired make up of the center. ${ }^{27}$ In sum, it is essential that realistic priorities be established and that it be recognized that "social" goals may have to be deferred for some time.

A closely related political goal of the community corporation which poses challenges is the desire for community participation. The objective of creating a "cohesive unit in the ghetto" through involving a maximum number of people in the decision making process of the community corporation is one which has proved to be largely impractical. In its survey of CDC's, the Harvard Law Review found

\footnotetext{
${ }^{25}$ The CaMbridge Institute, stipta note 15 , at 8.

${ }^{20} \mathrm{Id}$, at $\mathrm{I} 7$.

${ }^{27}$ Sturdivant, supra note 16 , at 126 .
} 
that "In practice there has been little community-wide participation in all but a very few community corporations."28 Generally, the control of the corporations rests in the hands of the leaders who established them. "This concentration of control appears to be due in large part to the need to devote almost all energies to establishing a viable business organization, rather than expending efforts to inform, motivate, and organize large numbers of community persons."29

Again, this political objective appears to be in fundamental conflict with the economic objective of creating a viable enterprise. Frances Fox Piven has suggested that "The corporation is not an organism which lends itself to democratic control by shareholders, as any scrutiny of private corporations in America will confirm ... [because of] ... the tendency of a corporation management to acquire control by the mere fact of constant involvement in intricate corporation affairs." ${ }^{30}$ To a great extent the lack of democracy is related to shareholder apathy. Shareholders with relatively small investment in a corporation have little incentive to participate in forums designed for shareholder involvement. This problem is even more complicated in a ghetto setting because of the disillusionment experienced in the past. Getting local residents to invest in a community corporation and participate actively in its public meetings would be a formidable task. One critique of the Community Self-Determination Bill stressed this point by noting that:

if shareholders are to retain their shares in the corporation and are to participate actively in its functions, and if new shareholdres are to be encouraged to invest after formation, then concrete benefits must derive from stock ownership. However, unlike investors in business corporations, shareholders in the CDC cannot realize capital gains because of the restriction on transferability and the continuing offer of shares by the CDC at the five dollar par value. Moreover, distribution of CDC profits to shareholders ordinarily may be made only in the form of community services. Intangible considerations, such as community pride or pride in being a shareholder-owner of visible and tangible assets, may serve to secure participation at the outset, but these are thin reeds on which to rest a continuing financial commitment by the poor. ${ }^{31}$

Even if community development corporations were allowed to pay cash dividends to their shareholders, it is clear that their ghetto enterprises generally will be starved for capital and any profits generated for the forseeable future should be retained in the businesses.

\section{B. Compatibility of Social Service and Economic Goals}

The lack of compatibility between political and economic goals is closely related to the conflict between social and economic objectives. If social services are to be

\footnotetext{
${ }^{28}$ Community Development Corporations: Operations and Financing, supra note 3 , at 1582 .

${ }^{20} I d$. at 1582 .

${ }^{30}$ Piven, Community Control: Beyond the Rhetoric, NEw Generation, Fall, I968, at 7, 8.

${ }^{81}$ Community Development Corporations: $A$ New Approach to the Poverty Program, supra note 22, at $649-50$.
} 
provided to the community by the corporation then profits must be generated by the corporation's enterprises. Since it is highly unlikely that the enterprises can be effectively managed by means of a democratic decision-making process, the most visible benefits to be derived by the local residents will be the social services. Again, the community corporation faces a difficult problem, as suggested by Louis Smith of Operation Bootstrap in Los Angeles: "If people think you're going to start a business and that business is going to generate any real capital to put back into your community, you're really thinking in terms of years."32

While community corporations have been largely unable to contribute to the improvement of health, recreation, housing, and medical services in their communities, they offer other social benefits that are of major importance. By creating businesses of any reasonable scale in the ghetto the corporations are providing training to the unskilled, employment to the unemployed, management development opportunities to blacks who might otherwise face racial barriers on the outside, and a model of business adventure for the younger members of the community. Simply by accepting the challenge of locating in the ghetto and hiring and training local people the corporations have incurred a "social service overhead" which makes their long-range viability that much more difficult. Perhaps one of the major weaknesses of this form of organization is that these basic, enterprise-building activities may not be viewed as being sufficiently dramatic to enlist the support of the community and therefore the organizations may undertake other social services before being in a sufficiently sound economic position to support them.

Frances Fox Piven suggested that "On its own, the ghetto seems better described as an economic backwater than an economic colony, the sluggish backwater of a swift and dynamic economy." ${ }^{\text {"3 }}$ Even a brief review of the economic environment in the ghetto suggests that it is far from being a fertile field for business growth. The costs of conducting business there, the limited resources, and the general hostility toward business help explain why the black ghetto has been left to stagnate while the economy of the dominant society has moved ahead at a rapid rate. After first being victimized by racism its residents have become the victims of opportunity costs. In general, there have simply been too many profitable alternatives to investing in or conducting business in the ghetto.

It is of paramount importance, therefore, that it be clearly understood that the establishment of viable enterprises in the ghetto is extremely difficult. It requires imaginative leadership, resourceful management, and substantial funds to create the kinds of enterprises that will transform the economic status of the ghetto. These enterprises must overcome the environmental problems, such as higher costs, and be capable of competing with companies from the general market. It must also be recognized that economic development is a long and difficult process whether it be

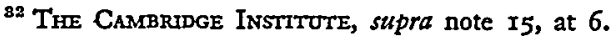

${ }^{88}$ Piven, supra note 30 , at 8 .
} 
Nineteenth Century America or the five year plans in the Soviet Union or China and it is unrealistic to assume that the process can be speeded without the infusion of outside capital and technical assistance. As Bayard Rustin has stated, "we have to get rid of this idea that people can lift themselves by their bootstraps. No social class has ever got out of being in the lumpen proletariat except by social engineering." "34

This process of social engineering requires the involvement of local groups such as community development corporations, government, and the business system in general. Conceding the fact that local involvement poses certain managerial problems, the notion of local participation is still one of the essential strengths of the CDC concept. If it can be accomplished, at least to the extent of communicating to the community that local people are controlling the direction the economic development is taking, then the general atmopshere for the conduct of business can be improved sharply. On the other hand, the most serious weakness of the concept is the danger of confused objectives. The primary objective must be the establishment of self-sufficient, viable enterprises which are capable of attracting the necessary financial, technical, and managerial resources. In short, many of the broader social service benefits must be viewed as long-range. Shareholders and managers alike must recognize that if resources are to be attracted and utilized effectively the objectives of local control and democratic rule by the area residents must be subordinated.

In communities which enjoy imaginative and strong leaders with a commitment to sound management practices and the capacity to raise the capital for seed money, these compromises should be minimal and relatively painless. Unfortunately, such conditions are found in a minority of locations where community corporations are presently in operation. Thus, while in some cases the community-based development corporation represents a promising and exciting approach to economic development, in a majority of situations the mixed objectives and managerial problems associated with the community decision-making process will probably condemn the local corporation to failure.

These strengths and weaknesses of the community corporation approach to economic development reinforce the view that a variety of approaches must be attempted in dealing with the plight of the ghetto. Among the unfortunate features of the debate which centered around the Community Self-Determination Bill were the claims made for the CDC approach by its more enthusiastic supporters. In discussing the bill, Oscar A. Ornati observed that "there is clearly nothing wrong with the Act as one more tool in the kit of national anti-poverty policies. What is wrong and fundamentally dangerous are the claims made for it. . . . [T] $]$ he wellbeing of slum inhabitants can come only through many and massive national programs geared to maximum employment, effective markets, the ending of discrimination, and more health, housing, and education."35

\footnotetext{
${ }^{84}$ J. Hund, supra note 9, at 6 .

${ }^{85}$ Ornati, $A$ Noble Cop-Out, New Generation, Fall, rg68, at io.
} 
It was because of the recognition of a need for diversity in the approaches to dealing with black economic development that the American Assembly on that topic listed a series of approaches ranging from CDC's to the location of branch operations of big companies in the ghetto. In support of these efforts, it was recommended that a Marshall Plan commitment of resources be made by the federal government to be coordinated by a "National Development Corporation." This program was to be supported by the creation of a network of regional discount banks to stimulate the infusion of capital and other programs including tax incentives to offset the higher costs of doing business in the ghetto. ${ }^{36}$ The attack must be made on a wide front utilizing a variety of vehicles for economic development. The community-based corporation is one such vehicle, but alone it offers relatively little promise because of its organizational weaknesses.

${ }^{88}$ T. Cross, supra note I2, at 5-9. For the background papers used by the Assembly, see BLAck Econonic Development (W. Haddad \& G. Pugh eds. rg69). 